Journal of Applied Veterinary Sciences, 7 (1): 18-23 (January, 2022).

ISSN: Online: 2090-3308, Print: 1687-4072

Journal homepage : https://javs.journals.ekb.eg

\title{
Histological and Clinical Finding of Systemic Melatonin on Wound Healing after Tooth Extraction in Rabbits.
}

\author{
Ghada A. Taqa and Shahad S. Albanna*
}

Department of Dental Basic Science, College of Dentistry, University of Mosul, Mosul, Iraq.

*Corresponding Author: Shahad S. Albanna, E-Mail: Shahad.dep55@student.uomosul.edu.iq

\begin{abstract}
This study aimed to evaluate the effects of systemic melatonin on wound healing after tooth extraction. This study was conducted on twenty healthy adult male New Zealand albino rabbits. Tooth extraction was done on all rabbits, and then animals were divided into two major groups. Control group $(n=10)$ : received no treatment. Melatonin treated group $(n=10)$ : received melatonin orally $(1 \mathrm{mg} \backslash \mathrm{kg})$ dissolved in distilled water; gave it to the rabbits once daily for a determined period. On days seventh and fourteenth, all animals in each group were sacrificed. The wound area site undergoes histological examination to compare the healing among the control group and melatonin treated group. The present study demonstrated that melatonin treated group found to accelerate wound healing manifested by a score of angiogenesis $(1.6 \pm 0.54)$, granulation tissue $(2 \pm 0.70)$ and reepithelization $(1.2 \pm 0.44)$ while a decrease in inflammatory cells $(0 \pm 0.00)$ in comparison to control group at $7^{\text {th }}$ and $(2 \pm$ $0.70),(2.2 \pm 0.44),(2.6 \pm 0.54)$ respectively and decrease in inflammation $(0 \pm$ $0.00)$ at the $14^{\text {th }}$ day. In this study, we found that systemic melatonin accelerates socket wound healing after tooth extraction.
\end{abstract}

\section{Original Article:}

DOI:https://dx.doi.org/10.21608/javs.2 021.98538.1107

Received :28 September, 2021. Accepted :20 November, 2021. Published in January, 2022.

This is an open access article under the term of the Creative Commons Attribution 4.0 (CC-BY) International License. To view a copy of this license, visit:

http://creativecommons.org/licenses/by/4.0/

Keywords: Antioxidant, Melatonin, Reepithelization, Socket wound healing,Tooth extraction.

\section{INTRODUCTION}

Tooth extraction initiates a series of reparative processes including both hard tissue (i.e., alveolar bone) and soft tissues (periodontal ligament, gingiva) (Farina and Trombelli, 2011). Several alterations occur after tooth extraction, both histologically and clinically. A blood clot forms then are replaced by granulation tissue, which is then replaced by mineralized, immature, woven bone in the first 6-8 weeks following an extraction. However, bone remodeling will yield mature bone in the next 16-18 weeks, with little consistency among patients. In fact, in some patients, the process of bone remodeling may not be finished by the end of these 24 weeks (Kulkareni et al., 2019).

Accelerate wound healing after a tooth extraction is helpful in dental treatment (Khoswanto, 2019). The use of antioxidants such as melatonin may support wound healing after tooth extraction (Sharafati-Chaleshtori et al., 2017). Lerner et al., (1958) discovered melatonin (Nacetyl5methoxytryptamine), an indoleamine, in the bovine pineal gland in 1958 (De Rensis et al., 2020). It's a pineal glandproduced circadian endocrine molecule that was first identified as a factor in regulating physiological systems and processes, including circadian rhythms, Immune system, cardiovascular system, reproduction, hormone secretion, accelerates wound healing and aging process (Hardeland, 2017).

Exogenous melatonin has hypnotic/sedative effects, improves angiogenesis phases of wound healing, counteracts immune deficiencies, changes the timing of fatigue and sleep, acts as an acute sleepinessinducing, and affects circadian rhythms and general health. (Barriga et al., 2001). A recent study found that melatonin ameliorates autistic-like behavior induced in pups of rats ( Taqa et al., 2021). Melatonin is said to have both receptor-mediated and receptorindependent effects (for example, radical scavenging) actions(Imenshahidi et al., 2020). Therefore, this study aims to evaluate melatonin's clinical and histological effect on socket wound healing after tooth extraction.

\section{MATERIALS AND METHODS}

The research was conducted at the Department of Dental Basic Science, College of Dentistry, University of Mosul, Iraq. 


\section{Animals:}

Twenty healthy adult male white albino rabbits with a weight range from (1.5- 2.5) $\mathrm{Kg}$, aged (5-6) months used in this study. The animals were housed in normal conditions, including ad libitum feeding (wheat and fresh vegetables), housing at (25) ${ }^{\circ} \mathrm{C}$ room temperature, and a 12-hour lighting and 12-hour darking system (Ayranci $\boldsymbol{e t}$ al., 2016). The animal was held in a cage at the University of Mosul's College of dentistry's animal house. A veterinarian examined the animals to determine their general health and condition prior to surgical procedure.

\section{Surgical procedure:}

Ketamine hydrochloride $(40 \mathrm{mg} / \mathrm{kg})$ and xylazine $(5 \mathrm{mg} / \mathrm{kg})$ injections were administered intramuscularly to anesthetize the rabbits (Salduz et al., 2017) within 5 minutes, complete anesthesia had been achieved. The animals were put in a left lateral position on the operation table, and the left central incisor was separated from the upper jaw using a standardized sterile procedure.

\section{Experimental Protocol:}

This study was conducted on twenty healthy adult male New Zealand albino rabbits. Tooth extraction was done on all rabbits (Fig. 1, A and B) and then animals were divided into two major groups. Control group $(\mathrm{n}=10)$ : received no treatment. Melatonin treated group $(n=10)$ : received melatonin $(1 \mathrm{mg} \backslash \mathrm{kg}$ ) systemically gave it by mouth once time daily for a determined period time (Fig.2, A and B). On days seventh and fourteenth, all animals in each group were sacrificed and underwent histological examinations. The area of socket wound site was performed to compare the healing of the control and melatonin-treated groups.

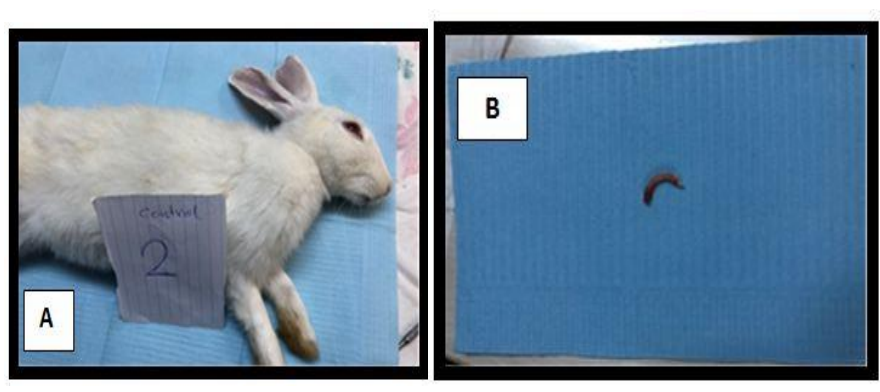

Fig.1: A: Picture of the anesthetized rabbit .B: Rabbits Tooth after extraction.

\section{Post-Operative Care:}

Immediately after the procedure, the rabbits were separated until they recovered from anesthesia. Observation of the feeding and physical activity of the operated animals during the first 24 hours after surgery.
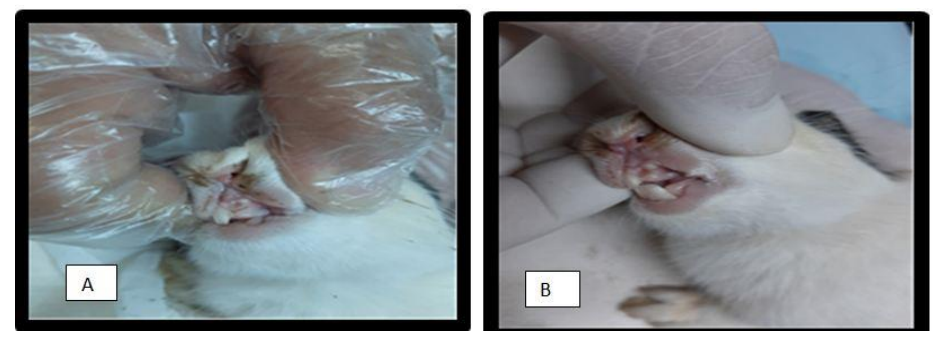

Fig.2: A: On the seventh day of treatment. B: On the fourteenth day of treatment.

\section{Histopathopathological examination:}

On the $7^{\text {th }}$ and $14^{\text {th }}$ day of treatment, all animals were sacrificed for histopathological examination of the oral mucosal wound of the socket. The tissue was fixed, processed and stained by Hematoxylin and Eosin, then examined under a light microscope, and the criteria of histopathological examination were according to (Gupta and Kumar, 2015; Lucaciou $\boldsymbol{e t}$ al., 2015; Salim and Munawah, 2020)

\section{Statistical analysis:}

The data were expressed as mean $\pm \mathrm{SD}$, and the variance between two experimental sets was statistically analyzed using Non-parametric analysis and a two-sample Mann-Whitney $U$ test. The significance threshold was set at $\mathrm{P}<0.05$ (Ali and Bhaskar, 2016).

\section{RESULTS}

\section{On day 7: Control group:}

The microscopic investigation of histological slides representing by peripherally present newly blood vessels (angiogenesis), the histopathological score's mean value was $(1.4 \pm 0.54)$, scanty amount of granulation tissue, the mean value of histopathological score was $(1.6 \pm 0.54)$, and inflammatory infiltration the histopathological score's mean value was, $(1.8 \pm$ 0.83 ) without reepithelialization the mean value of histopathological score was $(0 \pm 0.0)$ (Table 1 ; Fig. 3, 4).

Table 1: Histopathological Finding of Socket wound healing that treated systemically. (Mean \pm standard deviation) on day 7 .

\begin{tabular}{|c|c|c|c|c|}
\hline 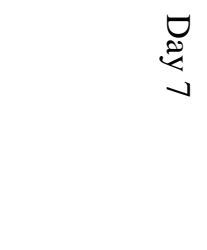 & 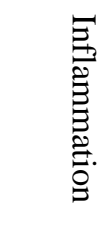 & 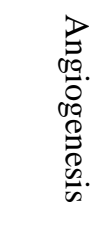 & 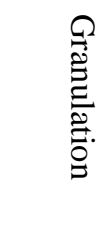 & 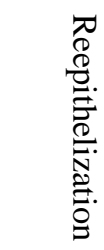 \\
\hline Control & $\begin{array}{l}1.8 \pm \\
0.83\end{array}$ & $\begin{array}{l}1.4 \pm \\
0.54\end{array}$ & $\begin{array}{l}1.6 \pm \\
0.54\end{array}$ & $\begin{array}{c}0.0 \pm \\
0.0\end{array}$ \\
\hline Melatonin & $\begin{array}{c}0 \pm \\
0.00\end{array}$ & $\begin{array}{l}1.6 \pm \\
0.54\end{array}$ & $\begin{array}{l}2.0 \pm \\
0.70\end{array}$ & $\begin{array}{l}1.2 \pm \\
0.44\end{array}$ \\
\hline P-value & 0.005 & 0.55 & 0.339 & 0.004 \\
\hline
\end{tabular}




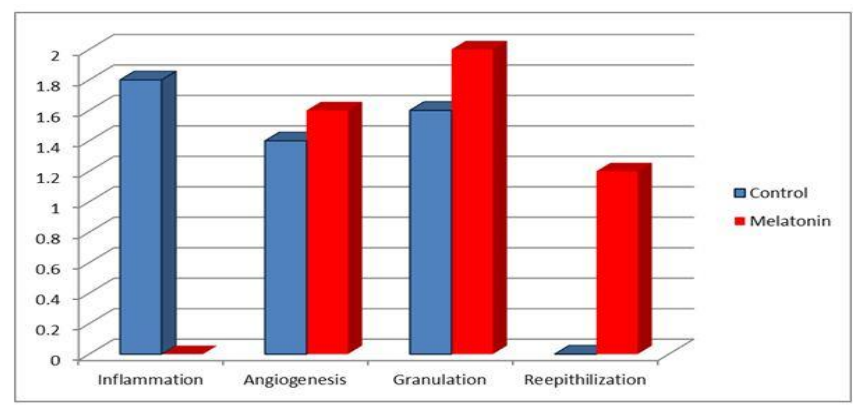

Fig. 3: Mean rank differences between control and systemically melatonin treated groups on the $7^{\text {th }}$ day of healing for inflammation, Angiogenesis, Granulation and Reepithelization.

\section{Group treated with melatonin systemically:}

The microscopic investigation of histological slides shows the site of wound represented by peripherally present newly blood vessels (angiogenesis), the mean value of histopathological score $(1.6 \pm 0.54)$, moderate amount of granulation tissue, the mean value of histopathological score was $(2 \pm 0.70)$, without inflammatory infiltration, the histopathological score's mean value was $(0 \pm 0.00)$ and reepithelialization bellow the half of the wound, the mean value of histopathological score was $(1.2 \pm$ 0.44) (Table 1; Figs. 3 and 4).
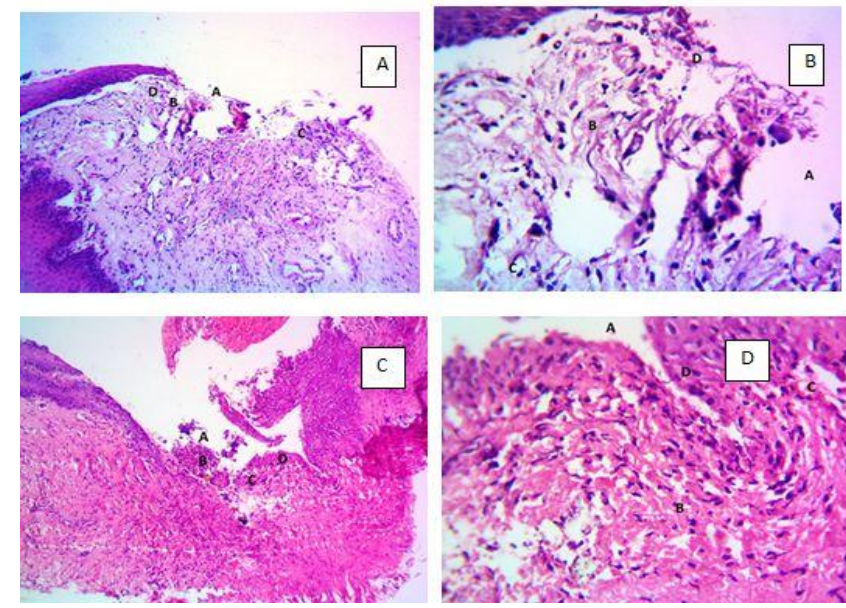

Fig. 4: Seven day period of the histopathological section of the tooth socket:

A: photomicrograph of socket wound of control group shows (A) representing by the scanty amount of granulation tissue (score 1) (B), peripherally present newly blood vessels (angiogenesis) (score 1), (C), and inflammatory infiltration (score 1) without reepithelialization (score 0) (D).100X.

B: photomicrograph of socket wound of control gp representing by (A) scanty amount of granulation tissue (score 1) (B), peripherally present newly blood vessels (angiogenesis) (score 1), (C), and inflammatory infiltration (score1) without reepithelialization (score 0) (D), 400X

C: photomicrograph of socket wound of melatonin group (A) representing by a moderate amount of granulation tissue (score 2) (B), peripherally present newly blood vessels (angiogenesis) (score 1), (C), without inflammatory infiltration (score 0 ) and reepithelialization bellow the half of the wound (score 1) (D). 100X.

D: photomicrograph of socket wound of melatonin group (A) representing by a moderate amount of granulation tissue (score 2) (B), peripherally present newly blood vessels (angiogenesis) (score 1), (C), without inflammatory infiltration (score 0 ) and reepithelialization bellow the half of the wound (score 1) (D). 400X.
On Two independent Sample (Mann Whitney $\mathrm{U})$, the Statistical test showed that the mean of the melatonin-treated group is higher than that of the control group for inflammation and reepithelization. Pvalue was less than 0.05 , which indicates a significant difference in inflammation and reepithelization between the two groups. In contrast, the P-value of angiogenesis and granulation was more than 0.05 , showing a non-significant difference between melatonin and the control group.

\section{On day 14 :}

\section{Control group:}

Photomicrograph of socket wound of control group shows the site of wound representing by peripherally present newly blood vessels (angiogenesis), the histopathological score's mean value was $(1.6 \pm 0.54)$, scanty amount of granulation tissue, the mean value of histopathological score was $(1.4 \pm 0.54)$, inflammatory infiltration, the histopathological score's mean value was $(1.4 \pm 0.54))$ and reepithelialization bellow the half of the wound, the mean value of histopathological score was $(1.2 \pm 0.44)$.

\section{Melatonin treated group (Systemically):}

Photomicrograph of socket wound of melatonin group shows the site of wound representing by peripherally and centrally present newly blood vessels (angiogenesis), the mean value of histopathological score was $(2 \pm 0.70)$, a moderate amount of granulation tissue, the histopathological score's mean value was $(2.2 \pm 0.44),(C)$, without inflammatory infiltration, the mean value of histopathological score was $(0 \pm 0.0)$ and irregular full thickness of reepithelialization of the wound is the histopathological score's mean value was $(2.6 \pm 0.54)$ (Table 2; Figure 5 and 6).

Table2: Histopathological Finding of Socket wound healing that treated systemically at $14^{\text {th }}$ day (mean \pm standard deviation).

\begin{tabular}{|c|c|c|c|c|}
\hline $\begin{array}{l}\underset{\otimes}{\Perp} \\
\underset{\not}{\Perp}\end{array}$ & 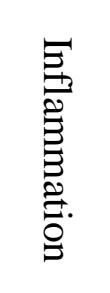 & 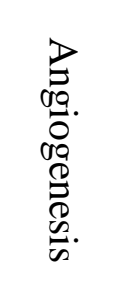 & 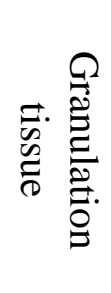 & 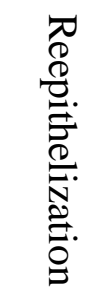 \\
\hline Control & $\begin{array}{l}1.4 \pm \\
0.54\end{array}$ & $\begin{array}{l}1.6 \pm \\
0.54\end{array}$ & $\begin{array}{c}1.4 \pm \\
0.54\end{array}$ & $\begin{array}{l}1.2 \pm \\
0.44\end{array}$ \\
\hline Melatonin & $\begin{array}{c}0.0 \pm \\
0.00\end{array}$ & $\begin{array}{c}2.00 \pm \\
0.70\end{array}$ & $\begin{array}{c}2.2 \pm \\
0.44\end{array}$ & $\begin{array}{c}2.6 \pm \\
0.54\end{array}$ \\
\hline P-value & 0.005 & 0.339 & 0.042 & 0.011 \\
\hline
\end{tabular}




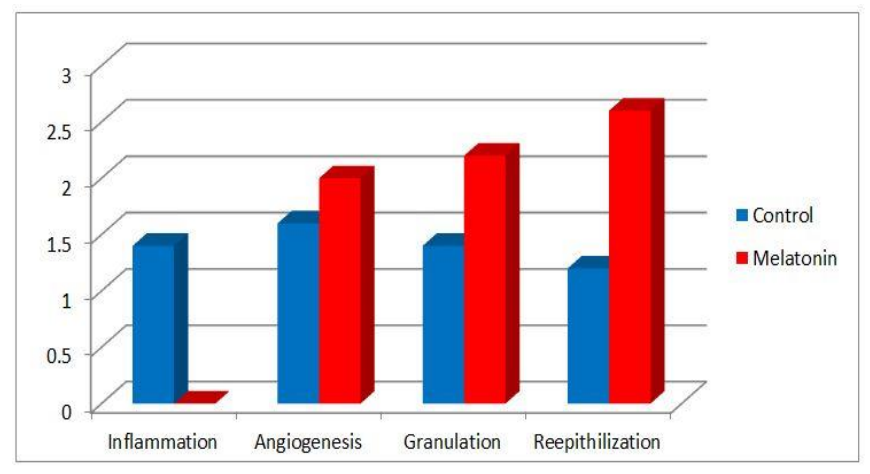

Fig. 5: Mean rank differences between control and systemically melatonin treated groups on the $14^{\text {th }}$ day of healing for inflammation, Angiogenesis, Granulation and Reepithelization.

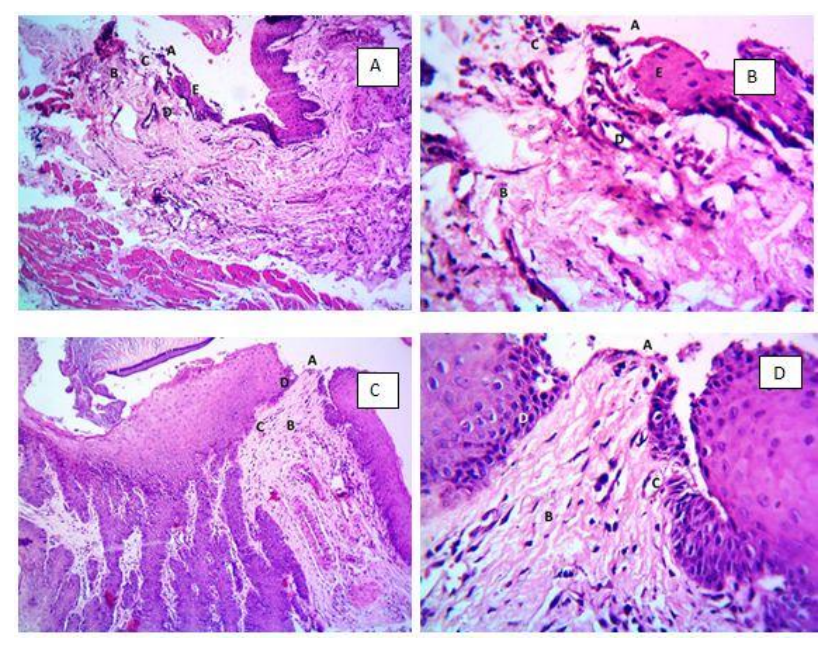

Fig. 6: Fourteenth day period of the histopathological section of the tooth socket.

A: photomicrograph of socket wound of the control group (A) representing by the scanty amount of granulation tissue (score 1) (B), peripherally present newly blood vessels (angiogenesis) (score 1), (C), inflammatory infiltration (score 1) and reepithelialization bellow the half of the wound (score 1) (D) 100X.

B: photomicrograph of socket wound of the control group (A) representing by the scanty amount of granulation tissue (score 1) (B), peripherally present newly blood vessels (angiogenesis) (score 1), (C), inflammatory infiltration (score 1) and reepithelialization bellow the half of the wound (score 1) (D) 400X.

C: photomicrograph of socket wound of treated group (A) representing by a moderate amount of granulation tissue (score 2) (B), peripherally and centrally present newly blood vessels (angiogenesis) (score 2), (C), without inflammatory infiltration (score 0) and irregular full thickness of reepithelialization of the wound area (score 3) (D).100X.

D: photomicrograph of skin wound of melatonin group (A) representing by a moderate amount of granulation tissue (score 2) (B), peripherally and centrally present newly blood vessels (angiogenesis) (score 2), (C), without inflammatory infiltration (score 0) and irregular full thickness of reepithelialization of the wound area (score 3) (D).400X.

On Two independent Sample (Mann-Whitney $\mathrm{U}$ test), the statistical test showed that the mean of melatonin treated group is higher than of control group for inflammation, granulation and reepithelization, at
P-value $\leq 0.05$ which indicate there is a significant difference in inflammation, granulation and reepithelization between two groups while $\mathrm{P}$-value of angiogenesis was found to be more than 0.05 which indicate a non-significant difference between melatonin and control group.

\section{DISCUSSION}

The natural wound healing process is a primary goal of every surgical procedure (Yeyen et al., 2013). Wound healing is a multi-step process that begins with the inflammation and progresses through granulation tissue formation, angiogenesis, re-epithelization, and wound contraction (Taqa et al ., 2014).

In this research, we found that melatonin accelerates wound healing after tooth extraction in rabbits; these results agree with the previous study that shows melatonin accelerates normal wound healing in rats by interacting with and modulating key biological processes such as inflammation, angiogenesis, collagen synthesis, and scar formation that drive the wound healing response (Pugazhenthi et al., 2008).

This project showed a decline in the inflammatory response in groups treated with systemic melatonin. This agreement with Xu et al., (2020) who reported that melatonin is a bioactive substance that can effectively promote muscle recovery by inhibiting oxidative stress and inflammation.

Acute inflammation and chronic inflammation stages occur during the inflammation stage, and Macrophages are cells that actively contribute during the chronic inflammation stage. Macrophages perform phagocytosis, collagen synthesis, granulation tissue creation in cooperation with fibroblasts, growth factor generation, and angiogenesis (the formation of new capillaries) (Yulilati et al. 2020). According to Mei et al., (2002) that showed melatonin could regulate macrophage activity.

This study shows that the positive effect of melatonin on angiogenesis in the socket is supported and agreed with several studies like Soybİr et al., (2003) who found that after applying melatonin to wounds, the number of vessels increased. Jin $\boldsymbol{e t}$ al., 2018) said that melatonin sped up the healing process in diabetic mice. Mice in diabetes with the melatonin group had more capillaries than those in the diabetes group (Chen et al., 2021). Ma et al., (2020) showed melatonin has a positive effect on both angiogenesis and wound healing. Melatonin therapy also accelerated the angiogenic process by raising vascular endothelial growth factor protein, which increased the development of new blood vessels (VEGF) which is a 
major contributor to angiogenesis) expression during granulation tissue formation.

The current study's histopathological findings revealed significant variations in wound healing between control and melatonin-treated groups. using it increases the granulation tissue and reepithelialization and this agrees with Kaczmarek-Szczepańska $\boldsymbol{e t}$ al., (2021) that showed melatonin accelerates reepithelialization., On days 7 and 21. Jin et al., (2018) revealed that the diabetes group treated with melatonin had more collagen deposition than the diabetes group. Melatonin therapy increased arginase activity (which produces proline, a component of collagen formation) from earlier periods ( Ma, et al., 2020 ).

Melatonin's ability to speed wound healing in this study may be due to its ability to reduce oxidative stress. It is thought to have a far more substantial antioxidant impact than vitamins E, C, and glutathione. This property aids wound healing, as compared to traditional antioxidants, which neutralize one or less ROS, the molecule can capture up to ten (Tan et al., 2015).

\section{CONCLUSION}

This study showed that melatonin administration speeds up the healing process of the wound of a tooth socket. This is manifested by decreasing the inflammatory cells and increasing angiogenesis of blood vessels, granulation tissue formation, and reepithelization.

\section{Declaration of Conflicting Interests}

The authors revealed that there is no potential conflicts of interest.

\section{REFERENCES}

ALI, Z., and BHASKARr, S. B., 2016. Basic statistical tools in research and data analysis. Indian journal of anaesthesia, 60(9), 662. https://dx.doi.org/10.4103\%2F0019-5049.190623.

AYRANCI, B., KALENDER, A. M., SEVIMLI, R., KORKMAZ, M. F., and BILAL, O., 2016. The effect of tramadol HCL and paracetamol on fracture healing in rat tibia model. https://dx.doi.org/10.5455/medscience.2016.05.8527.

BARRIGA, C., MARTIN, M. I., TABLA, R., ORTEGA, E., and RODRIGUEZ, A. B., 2001. Circadian rhythm of melatonin, corticosterone and phagocytosis: effect of stress. Journal of Pineal Research, 30(3), 180-187.https://doi.org/10.1034/j.1600079X.2001.300307.x.

CHEN, K., TONG, C., CONG, P., LIU, Y., SHI, X., LIU, X., ZHANG, J., ZOU, R., XIAO, K., and NI, Y., 2021. Injectable melatonin-loaded carboxymethyl chitosan (CMCS)-based hydrogel accelerates wound healing by reducing inflammation and promoting angiogenesis and collagen deposition. Journal of
Materials Science \& Technology, 63, 236-245. https://doi.org/10.1016/j.jmst.2020.06.001.

DE RENSIS, F., MORINI, G., GARCIA-ISPIERTO, I., and López-Gatius, F., 2020. To what extent does photoperiod affect cattle reproduction? Clinical perspectives of melatonin administration. Annals of Animal Science Science, 2020, vol. 20, núm. 3, p. 797809.https://doi.org/10.1034/j.1600-079X.2001.300307.x.

FARINA, R., and TROMBELLI, L., 2011. Wound healing of extraction sockets. Endodontic Topics, 25(1), 16-43. https://doi.org/10.1111/etp.12016.

GUPTA, A., and KUMAR, P., 2015. Assessment of the histological state of the healing wound. Plastic and Aesthetic Research, 2, 239-242.

https://doi.org/10.4103/2347-9264.158862.

HARDELAND, R. 2017. Melatonin and the pathologies of weakened or dysregulated circadian oscillators. Journal of Pineal Research, 62(1), e12377. https://doi.org/10.1111/jpi.12377.

IMENSHAHIDI, M., KARIMIO, G., and HOSSENZAHED, H., 2020. Effects of melatonin on cardiovascular risk factors and metabolic syndrome: a comprehensive review. Naunyn-Schmiedeberg's Archives of Pharmacology, 393(4), 521-536. https://doi.org/10.1007/s00210-020-01822-4.

JIN, H., ZHANG, Z., WANG, C., TANG, Q., WANG, J., BAI, X., WANG, Q., NISAR, M., TIAN, N., and WANG, Q., 2018. Melatonin protects endothelial progenitor cells against AGE-induced apoptosis via autophagy flux stimulation and promotes wound healing in diabetic mice. Experimental \& Molecular Medicine, 50(11), 1-15.

https://doi.org/10.1038/s12276-018-0177-z.

KACZMAREK-SZCZEPANSKA, B., OSTROWSKA, J., KOZLOWSKA, J., SZOTA, Z., BROZENA, A. A., DREIER, R., REITER, R. J., SSLOMINSKI, A. T., STEINBRINK, K., and KLESZCZYNSKI, K., 2021. Evaluation of Polymeric Matrix Loaded with Melatonin for Wound Dressing. International Journal of Molecular Sciences, 22(11), 5658. https://doi.org/10.3390/ijms22115658.

KHOSWANTO, C. 2019. A new technique for research on wound healing through extraction of mandibular lower incisors in Wistar rats. European Journal of Dentistry, 13(02), 235-237. https://dx.doi.org/10.1055\%2Fs0039-1694312.

KULKARENI, S., MEER, M., and GEORGE, R., 2019. Efficacy of photobiomodulation on accelerating bone healing after tooth extraction: a systematic review. Lasers in Medical Science, 34(4), 685-692. https://doi.org/10.1007/s10103-018-2641-3.

LERNER, A. B., CASE, J. D., TAKAHASHI, Y., LEE, T. H., \& MORI, W. 1958. Isolation of melatonin, the pineal gland factor that lightens melanocyte S1. Journal of the American Chemical Society, 80(10), 2587-2587. https://doi.org/10.1021/ja01543a060

LUCACIO, O., GHEBAN, D., SORITAU, O., BACIUT, M., CAMPIAN, R. S., and BACIUTţ, G., 2015. Comparative assessment of bone regeneration by histometry and a histological scoring system. Revista Română de Medicină de Laborator Vol, 23(1). https://sciendo.com/article/10.1515/rrlm-2015-0009. 
MA, Q., REITER, R. J., and CHEN, Y., 2020. Role of melatonin in controlling angiogenesis under physiological and pathological conditions. Angiogenesis, 23(2), 91-104. https://doi.org/10.1007/s10456-019-09689-7.

MEI, Q., YU, J.-P., XU, J.-M., WEI, W., XIANG, L., and YUE, L., 2002. Melatonin reduces colon immunological injury in rats by regulating activity of macrophages. Acta Pharmacologica Sinica, 23(10), 882-886. https://pubmed.ncbi.nlm.nih.gov/12370092/.

PUGAZHENTHI, K., KAPOOR, M., CLARKSON, A. N., HALL, I., and APPLETON, I., 2008. Melatonin accelerates the process of wound repair in full-thickness incisional wounds. Journal of Pineal Research, 44(4), 387-396. https://doi.org/10.1111/j.1600-079X.2007.00541.x.

SALDUZ, A., DIKICI, F., KILICOGLU, Ö. I., BALCI, H. I., AKGUL, T., KURKCU, M., KURTOGLU, C., and TOZUN, R., 2017. Effects of NSAIDs and hydroxyapatite coating on osseointegration: Biomechanical and histological study on rabbits. Journal of Orthopaedic Surgery, 25(1), 2309499016684410.

https://doi.org/10.1177\%2F2309499016684410.

SALIM, H. A., and MUNAWAH, B. S., 2020. Histopathological Effects of Histoacryl on Oral Secondary Wound Healing: A Comparative Experimental Study. Al-Rafidain Dental Journal, 13(3), 515-523. http://dx.doi.org/10.33899/rden.2020.165388.

SHARAFATI-CHALESHTORI, R., SHIRZAD, H., RAFIEIAN-KOPAEI, M., and SOLTANI, A., 2017. Melatonin and human mitochondrial diseases. Journal of research in medical sciences: the official journal of Isfahan University of Medical Sciences, 22.https://dx.doi.org/10.4103\%2F1735-1995.199092

SOYBIR, Gü., TOPUZLU, C., ODABAS, Ö., DOLAY, K., BILIR, A., and KOKSOY, F., 2003. The effects of melatonin on angiogenesis and wound healing. Surgery Today, 33(12), 896-901. https://doi.org/10.1007/s00595-003-2621-3.

TAN, D.-X., MANCHESTER, L. C., ESTEBANZUBERO, E., ZHOU, Z., and REITER, R. J., 2015. Melatonin as a potent and inducible endogenous antioxidant: synthesis and metabolism. Molecules, 20(10), 18886-18906.

https://doi.org/10.3390/molecules201018886.

TAQA, G. A., MUSTAFA, E. A., and Al-HALIEM, S. M., 2014. Evaluation of Anti-Bacterial and Efficacy of plant extract (Urtica urens) on Skin Wound Healing in Rabbit. International Journal of Enhanced Research in Science Technology \& Engineering, 3(1), 64-70. http://www.erpublications.com/.

TAQA, G.A. Al-SHEIKH, H.A., and Al-ALLAF, L.I., 2021. Effects of Melatonin on Behavioural Activities in Acetaminophen-induced Autism in Rat. Journal of Applied Veterinary Sciences. https://journals.ekb.eg/article_193738_0.html.

XU, Y., CHEN, X., QIAN, Y., TANG, H., SONG, J., QU, X., YUE, B., and YUAN, W., 2020. Melatonin-Based and Biomimetic Scaffold as Muscle-ECM Implant for Guiding Myogenic Differentiation of Volumetric Muscle Loss. Advanced Functional Materials, 30(27),
2002378. https://doi.org/10.1002/adfm.202002378.

YEYEN, S., KARAKAS, D. O., BUDAK, E. T., and YILMAZ, I., 2013. The effects of different concentrations of epinephrine adjuvant to levobupivacaine on wound healing. Archives of Clinical and Experimental Surgery (ACES), 2(2), 9296. http://dx.doi.org/10.5455/aces.20121002024412.

YULIIATI, K. T., RANANDA, I., and SOESILAWATI, P., 2020. Increasing macrophages in tooth extraction wound healing after induction of freeze-drying gel Aloe vera $90 \%$ on Cavia cobaya. Malaysian J Med Heal Sci, 16(4), 87-91. https://medic.upm.edu.my/upload/dokumen/2020070 611253117_MJMHS 0164.pdf

How to cite this article:

Ghada A. Taqa and Shahad S. Albanna, 2022.

Histological and Clinical Finding of Systemic Melatonin on Wound Healing after Tooth Extraction in Rabbits. Journal of Applied Veterinary Sciences, 7 (1): $18-23$. DOI:https://dx.doi.org/10.21608/javs.2021.98538.1107 